Psychological Medicine, 1982, 12, 695-700

Printed in Great Britain

\title{
EDITORIAL
}

\section{The neuropathology of schizophrenia ${ }^{1}$}

The distinguished American neurologist, Plum (1972), once called schizophrenia 'the graveyard of neuropathologists'. Certainly the topic of neuropathological change in schizophrenia has been nearly as silent as a tomb for almost three decades. Interest in the neuropathology of schizophrenia was still high in 1952 when leading neuropathologists of the world, meeting at the First International Congress of Neuropathology in Rome, devoted many hours to formal presentations and discussions of pathological material from schizophrenic patients who died in mental hospitals on both sides of the Atlantic. Although more than 250 published papers had already appeared concerning the pathology of schizophrenia or dementia praecox prior to this Congress, neither the previous work nor the new material presented led to a consensus of opinion as to the neuropathological characteristics of this common disorder. On the contrary, perusal of the Congress Proceedings suggests that a dichotomy of views emerged, with most of the central European investigators, maintaining, as they had in earlier reports, that rather specific changes occurred in basal ganglia (Hopf, 1952; Vanderhorst, 1952; Fungfeld, 1952), basal forebrain (Buttlar-Brentano, 1952), or cerebral cortex (Josephy, 1930; Buscaino, 1924; Fungfeld, 1952; Hyden, 1952). Their colleagues from England and America, on the other hand, generally reported non-specific alterations which they attributed to convulsive treatments, surgical, agonal or post-mortem changes (Meyer, 1952; Rowland \& Mettler, 1949).

\section{NEURONE PATHOLOGY IN SCHIZOPHRENIA}

An exception was Bruetsch (1952) of Indianapolis, who maintained that a subgroup of approximately $9 \%$ of schizophrenics displayed minute acellular areas in the cortex secondary to rheumatic occlusive endarteritis. A similar observation was reported earlier by Winkelman \& Book (1949) and was confirmed by the Vogts (1952). Earlier findings included grape-like metachromatic globules in basal ganglia and white matter (Buscaino, 1924) and focal areas of demyelination (Ferraro, 1943). Josephy (1930) described lipoid accumulations in pyramidal neurones of layer II in pre-frontal cortex and hippocampus similar to those described by Spielmeyer (1931), as well as calcifications in globus pallidus and glial nodules in the basal ganglia, thalamus and brain stem.

Cecil and Oscar Vogt (1952), in a monumental series of studies commencing at the turn of the century, were the first to compare serial sections of whole brain specimens from schizophrenic patients and normal control subjects. Together with their collaborators they described numerous alterations in schizophrenic brains, including cell loss in cingulate and inferior temporal cortex, 'dwarf' cells (Schwarzellen) in basal ganglia and dorsal medial thalamus, apparently preceded by peculiar vacuolization and lipoid inclusions in clusters of neurones. From the same institute, Hopf (1952) reported 'dwarf cells' in basal ganglia of nine of ten patients with catatonic schizophrenia; Buttlar-Brentano (1952) described similar changes, i.e. progressive vacuolization, balloon cells, shrinkage and disappearance of cytoplasm in neurones in the nucleus basalis of substantia innominata, bed nucleus of stria terminalis, and periventricular, supraoptic, tuber and mammillary nuclei. Similar neuronal alterations and glial proliferation had been previously reported in hypothalamus, especially tuber cinereum by Dide (1934) and Morgan \& Gregory (1935).

Most neuropathologists of Great Britain and the United States remained sceptical, however, and in 1957 David, in an extensive review of the reported pathology of schizophrenia, dismissed

1 Address for correspondence: Dr Janice R. Stevens, Intramural Research Program, National Institute of Mental Health, Saint Elizabeths Hospitat. Washington, D.C.. USA. 
Buttlar-Brentano's observation of 'dwarf' cells in substantia innominata, commenting 'It is difficult to envisage how an alteration of as unspecific a region as this could have the systemic effects presumably required to induce schizophrenic behaviour.'

David suggested that only quantitative cell counts in schizophrenic and matched control material could confirm or deny the reports of focal neuronal degeneration. Negative results of such an undertaking had been previously reported for cerebral cortex by Dunlap (1929). Colon (1972) reached an opposite conclusion, finding a $70 \%$ reduction of neurones in cortical layers IV and V in selected areas of the frontal cortex of schizophrenic brains compared with controls. More recently, Dom et al. (1981) reported that cell counts on serial sections of basal ganglia and thalamus showed a $50 \%$ decrease in small neurones in pulvinar and large neurones in nucleus accumbens in brains of schizophrenics studied at the Vogt Institute. The difficulty of such studies are well known, and it is not surprising that psychiatrists turned with relief to the more easily quantified new technologies of gas-liquid chromatography, mass-spectrography and 'grinding and binding' for the measurement of biochemical constituents and receptor sites in schizophrenic and control brains.

The first International Congress of Neuropathology coincided with, but was too early to profit from, MacLean's (1952) heuristic introduction of limbic system anatomy pathology and physiology to psychiatry or David might not have dismissed Buttlar-Brentano's report of pathology in nucleus basalis so lightly. Assuming that the profound disturbances in higher nervous functions must involve cerebral cortex, a majority of studies of schizophrenic neuropathology has concerned cerebral cortex. Moreover, with few exceptions, the pathological material was generally stained only with conventional neuropathological techniques for myelin, Nissl substance and occasionally axis cylinders and lipoids.

\section{GLIAL CHANGES}

Employing the lithium carbonate stain for glia, Scharenberg (1952) reported a marked astrocyctic proliferation in cases of fatal catatonia. Five years later, Nieto, also using the lithium carbonate method, reported a pathological increase of fibrillary gliosis in periventricular and periaqueductal regions of the diencephalon and mesencephalon in a majority of schizophrenic brains. In a subsequent publication Nieto \& Escobar (1972), emphasized that the same sections of the brain displaying intense fibrillary gliosis with the lithium carbonate method were quite unremarkable in Nissl or myelin preparations. More recently, Fisman (1975) reported glial nodules in brain stem, especially the medial reticular area and trigeminal nucleus, in six of eight schizophrenic brains, noting a resemblance to viral, in particular herpes zoster, encephalitis. Both of these studies may be criticized as patients were generally of advanced age, the criteria for diagnosis were not specified, and material from 'blind' controls was not included.

Using stringent criteria for diagnosis of schizophrenia and restricting the specimens examined to patients under 54 years of age, we recently compared histological material from the brains of 28 patients meeting International Classification of Disease criteria for schizophrenia with similar material from age-matched non-schizophrenic control patients who died in the same hospital during the same period with a variety of neuropsychiatric disorders and with neuropathological material from age-matched patients deceased in a general hospital of medical or surgical causes (Stevens, $1982 a, b)$. Nissl, myelin or hematoxylin-eosin stains of this material revealed striking pathology in a few of the schizophrenic palients. A marked dropout of large neurones in the globus pallidus was apparent in three cases, and there was bilateral infarction in the inner or outer segment of pallidum in two cases. All five of these patients had admission diagnoses of catatonic schizophrenia and followed a course typical of chronic schizophrenia. Heavy deposits of iron-calcium concretions in globus pallidus, infiltration of the basal forebrain with corpora amylacea and abundant ependymal granulations, all common during middle and advanced age in normal controls' brains, were present in the brains of schizophrenic patients who died in their 20 s and $30 \mathrm{~s}$.

The most prominent and ubiquitous pathology, however, appeared only with the Holzer stain for glial fibrils. With this method, $70 \%$ of schizophrenic patients demonstrated increased fibrillary 
gliosis affecting primarily the periventricular regions and the anterior and inferior horns of the lateral ventricle, third ventricle, periaqueductal gray or basal forebrain. The gliosis was similar in distribution to that reported by Nieto (1957) and Nieto \& Escobar (1972). Although gliosis in mesencephalic tegmentum was also common, the discrete glial nodules described by Fisman (1975) were seldom seen. The location of gliosis varied greatly from case to case, being more pronounced in basal forebrain (substantia innominata, lateral hypothalamus, bed nucleus of stria terminalis) in certain cases, while in others periaqueductal, interpeduncular, dorsal medial thalamus or hypothalamic regions were principally affected. An attempt to correlate the subtype of schizophrenia with the pathological findings was entirely unsuccessful. This was not surprising, as a review of the clinical charts indicated that the patients diagnosed as catatonic schizophrenia on admission (as a majority were) generally proceeded during subsequent years of hospitalization to manifest flattened affect, isolation, delusions, ideas of reference, or pathological suspiciousness typical of paranoid schizophrenia. Subsequently, a majority progressed to states of abulic amotivational incoherent or hebephrenic behaviour or autistic preoccupation, with auditory hallucinations occasionally interrupted by episodes of severe agitation or assaultiveness. A correlation between location of the pathology and specific clinical phenomenology was sometimes suggestive - for example, sleep and feeding disturbances with hypothalamic gliosis, speech disturbance with pallidal pathology.

\section{VENTRICULAR ENLARGEMENT IN SCHIZOPHRENIA}

The introduction of computed tomography into psychiatric research (Johnstone et al. 1976) has led to a rediscovery of the ventricular dilatation so consistently reported in schizophrenic patients studied by pneumoencephalography more than half a century ago (Jacobi \& Winkler, 1927). The new evidence of ventricular enlargement must now direct attention once again to the long disputed neuropathological studies of schizophrenia. If the ventricles are enlarged, something must have disappeared. Although Weinberger et al. (1979) observed no correlation between lateral ventricular size and length of illness, Tanaka et al. (1981) reported a positive correlation between the size of the third ventricle and the duration of schizophrenia. If confirmed in serial studies of individual patients, this observation indicates that a progressive destructive process occurs in this disease. These radiological findings alone are sufficient reason to return to the study of the neuropathology of schizophrenia.

\section{SIGNIFICANCE OF MORPHOLOGICAL, ELECTROPHYSIOLOGICAL AND BIOCHEMICAL CHANGES FOR THE CONCEPT OF 'FUNCTIONAL PSYCHOSIS'}

As Yatsu, Professor of Neurology at the University of Oregon likes to say, 'Gliosis is a tombstone'. So, of course, are lipoid degeneration, cell dropout, mineral deposits, ependymal granulations and, probably, corpora amylacea. These neuropathological gravestones spur the search for aetiology. Such studies should now include techniques which have developed since the pioneering, but long neglected, studies of Alzheimer (1897), Dide (1934), the Vogts (1952), and so many others. Evidence for biological antecedents of schizophrenia has grown appreciably in the past decade with the explosion of growth in neurobiomedical technologies. Increased dopamine binding sites (Lee et al. 1978; Owen et al. 1978), increased norepinephrine in schizophrenic basal forebrain (Farley et al. 1980; Kleinman et al. 1982), abnormal EEG spectra (Stevens, 1976; Stevens et al. 1979; Fenton et al. 1980), enlarged cerebral ventricles (Johnstone et al. 1976; Weinberger et al. 1979), atrophy of cerebellar vermis (Weinberger et al. 1980), and evidence of immunological incompetence (Liederman \& Prilipko, 1976), autoimmunity (Semenov et al. 1961; Baron et al. 1977; Pandey et al. 1981) or viral residence in brain (Tyrell et al. 1979; Albrecht et al. 1980; Stevens, 1982 a; Torrey et al. 1982) all challenge long cherished notions of psychogenesis.

Chemical and morphological abnormalities in schizophrenia also raise questions about the increasingly obsolete concept of 'functional psychosis' and research diagnostic criteria which 
demand the exclusion of cases with evidence of organic brain disease from the schizophrenias.

Ferraro at the International Neuropathological Congress of 1952 enquired:

What should our attitude be in the presence of organic cerebral changes found in cases clinically diagnosed as functional psychosis?... Must we adhere to the concept that a diagnosis of schizophrenia is incompatible with the presence of cerebral pathology? Must we every time that organic changes are found in the brain of a supposedly schizophrenic patient change our diagnosis into one of organic psychosis simulating dementia praecox? Must we talk in such cases of schizophrenia-like condition?

Clearly, a new definition is required, encompassing new findings disclosed by new technologies. This is even more likely to be the case as the revolutionary changes in neuropathology which have followed the introduction of immunohistochemistry are applied to the study of receptors, enzymes. peptides, viruses, and immunological reactions in schizophrenic brains.

\section{EVIDENCE FOR UNITY AS WELL AS DIVERSITY OF THE SCHIZOPHRENIC SYNDROME: THE DOPAMINE HYPOTHESIS}

If the increased neuroleptic binding found in the basal ganglia and forebrain of schizophrenic brains is not related to neuroleptic treatment, this finding is the most consistent contribution to the pathology of schizophrenia in the last decade (Lee et al. 1978; Owen et al. 1978). How can an increase in putative dopamine binding sites in the striatum be integrated with the gliosis, cell metamorphosis or loss and ventricular enlargement which, up to now, have been the principal neuropathological findings of schizophrenia?

There are a number of clues that schizophrenia is due to an encephalopathy resulting from activation of a latent infectious agent. The seasonal peak of births in early spring of future schizophrenics (Torrey \& Torrey, 1979), the pockets of high incidence of schizophrenia in certain geographical areas (Torrey, 1980), and recent immunological findings in cerebrospinal fluid (Tyrell et al. 1979; Albrecht et al. 1980; Torrey et al. 1982) are consistent with repeated reactivation of a viral infection or immunological process in this disorder. Viruses and neurotransmitters bind to specific, apparently related, sites on neuronal membranes (Munzel \& Koschel, 1981; Lentz et al. 1982). Viruses may alter binding of other substances to the cell membrane and, following entry of the cell, can direct the metabolic machinery without necessarily destroying the host cell (Glasgow, 1979). Reportedly abnormal $T$ cell response to mitogens (Liederman \& Prilipko, 1976) and antibrain antibodies in serum (Semenov et al. 1961; Heath \& Krupp, 1967; Pandey et al. 1981) may also relate to the chronic residence of virus in brain.

The discovery of a viral aetiology for schizophrenia need not contradict the considerable evidence for hereditary factors in this disorder. Viral genome, incorporated in cell nucleus, can be transmitted with the genetic material of the host cell. If, as several studies suggest, cytomegalovirus, or varicella zoster virus, both members of the herpes family are associated with schizophrenia (Albrecht $e t a l$. 1980; Torrey et al. 1982; Stevens, 1982a), the reported amelioration of herpes zoster by treatment with L-dopa raises the possibility that virus and dopamine may compete for the same, or closely related, binding sites on neural membranes. The favourable effect of neuroleptics in schizophrenia could thus be only indirectly related to dopamine receptor blockade, but directly related to preventing viral binding and entry to the cell, to synaptosomes or to interference with replication of viral DNA within the cell (Hahn, 1979).

\section{NEEDED: A NEW SPECIALTY OF NEUROPSYCHIATRY OR PSYCHONEUROLOGY}

Neurologists have taken a long holiday from the study of psychiatry in general and from schizophrenia in particular. Equally remiss, an entire generation of psychiatrists has been trained with a curriculum often devoid of neuroanatomy, neuropathology and neurology, not to mention the explosion of new information and technology in neurochemistry, immunology, virology, and neuroradiology. In partial recognition of the growing similarity of both clinical problems and 
technologies in neurological and psychiatric research, American neurologists have recently given birth to the new subspecialty of behavioural neurology, deliberately avoiding the uncomfortable possibility that this concept might be better called psychiatry or, at the very least, neuropsychiatry. Pari passu, psychiatrists, at least those not exclusively enamoured of the psychotherapies (increasingly the province of non-medical professionals), have rediscovered the importance and excitement of the study of the brain. Few psychiatric training programmes provide adequate preparation for such work. Psychiatry's new horizons require retreading of practitioners as well as research physicians in the basic neurological sciences in order that the changes in these disciplines can be applied to the baffling clinical problems posed by the major psychoses. Clearly, neuropsychiatry (or psychoneurology) like its enormously successful young parents, the neurosciences, is a specialty whose time has come, and for which appropriate training programmes are urgently needed by both psychiatrists and neurologists.

JANICE R. STEVENS

\section{REFERENCES}

Albrecht, F., Torrey, E. F., Boone, E., Hicks, J. T. \& Daniel, N. (1980). Raised cytomegalovirus-antibody level in cerebrospinal fluid of schizophrenic patients. Lancet ii, 769-772.

Alzheimer, A. (1897). Beiträge zur pathologischen Anatomie der Hirnrinde und zur anatomischen Grundlage einiger Psychosen. Monatschrift für Psychiatrie und Neurologie 2, 82-119.

Baron, M., Stern, M., Anavi, R. \& Witz, J. P. (1977). Tissue binding factor in schizophrenic sera: a clinical and genetic study. Biological Psychiatry 12, 199-219.

Bruetsch, W. L. (1952). Specific structural neuropathology of the central nervous system (rheumatic, demyelinating, vasofunctional, etc.) in schizophrenia. In Proceedings of the First Imternational Congress of Neuropathology, Vol. 3, pp. 487-499. Rosenberg \& Sellier: Torino, Italy.

Buscaino, V. M. (1924). Histologic pathology and pathogenesis of dementia praecox, amentia, and extrapyramidal syndromes. Encephale 19, 217-224.

Buttlar-Brentano, K. (1952). Pathohistologische Feststellungen am basalkern Schizophrener. Journal of Nervous and Mental Disease 116, 646-653.

Colon, E. J. (1972). Quantitative cytoarchitectonics of the human cerebral cortex in schizophrenic dementia. Acta Neuropathology 20, $1-9$.

David, G. B. (1957). The pathological anatomy of the schizophrenias. In Schizophrenia: Somatic Aspects (ed. D. Richler), pp. 93-130. Pergamon Press: Oxford.

Dide, M. M. (1934). Les syndromes hypothalamiques et la dyspsychogenese. Revue Neurologique 6, 941-943.

Dom, R., de Saedleer, J., Bogerts, J. \& Hopf, A. (1981). Quantitational cytometric analyses of basal ganglia in catatonic schizophrenia. In Biological Psychiatry (ed. C. Perris, G. Struwe and B. Jansson), pp. 723-726. Elsevier: Amsterdam.

Dunlap, C. G. (1929). The pathology of the brain in schizophrenia. In Proceedings of the Association for Research in Nervous and Mental Disease. A Series of Research Publications, Vol. 8, pp. 371-377. Hoeber: New York.

Farley, I. J., Shannak, K. S. \& Hornykiewicz, O. (1980), Brain monoamine changes in chronic paranoid schizophrenia and their possible relation to increased dopamine receptor sensitivity. In Receptors for Neurotransmitters and Peptide Hormones (ed. G. Pepeu, M. J. Kuhar and S. J. Enna), pp. 427-433. Raven Press: New York

Fenton, G. W., Fenwick, P. B. C., Dollimore, J. L., Dunn, T. L. \& Hirsch, S. R. (1980). EEG spectral analysis in schizophrenia. British Journal of Psychialry 136, 445-455.

Ferraro, A. (1943). Histopathological findings in two cases clinically diagnosed dementia praecox. Journal of Nervous Disease and Experimental Neurology' 2, 84-94.
Ferraro, A, (1952). Discussion. In Proceedings of the First International Congress of Neuropathology, Vol. 3, pp. 631-634. Rosenberg \& Sellier: Torino, Italy.

Fisman, M. (1975). The brain stem in psychosis. British Journal of Psychiatry 126, 414-422.

Fungfeld, E. W. (1952). Pathologisch-anatomische Untersuchungen im nucleus anterior thalami bei Schizophrenie. In Proceedings of the First International Congress of Neuropathology, Vol. 3, pp. 648-659. Rosenberg \& Sellier: Torino, Italy.

Glasgow, L. A. (1979). Biology and pathogenesis of viral infections. In Viral Agents and Viral Diseases of Man (ed. G. J. Galasso, T. C. Merigan and R. A. Buchanan), pp. 39-76. Raven Press: New York.

Hahn, F. E. (1979). Anti-plasmid and antiviral effect of chlorpromazine. Naturwissenschaften 66, 467.

Heath, R. G. \& Krupp, I. M. (1967). Schizophrenia as an immunologic disorder. I. Demonstration of antibrain globulins by fluorescent antibody techniques. Archives of General Psychiatry 16, $1-9$.

Hopf, A. (1952). Uber histopathologische Veränderungen im pallidum and striatum bei Schizophrenie. In Proceedings of the First International Congress of Neuropathology, Vol. 3, pp. 629-635. Rosenberg \& Sellier: Torino, Italy,

Hyden, H. (1952). Nerve cell chemistry and neuropathological problems studied by means of quantitative methods. In Proceedings of the First International Congress of Neuropathology, Vol. 3, pp. 570-594. Rosenberg \& Sellier: Torino, Italy.

Jacobi, W. \& Winkler, H. (1927). Encephalographische Studien au chronisch Schizophrenen. Archiv für Psychiatrie und Nervenkrankheiten 81, 299-332.

Johnstone, E. C., Crow, T. J., Frith, C. D., Husband, J. \& Kreel, L. (1976). Cerebral ventricular size and cognitive impairment in chronic schizophrenia. Lancet ii, 924-926.

Josephy, H. (1930). Dementia praecox (Schizophrenie). In Dic Anatomie der Psychosen (ed. O. Bumke), pp. 763-778. Springer: Berlin.

Kleinman, J. E., Karoum, F., Rosenblatt, J. E., Gillin, J. C., Hong, J., Bridge, T. P., Zalcman, S., Storch, F., del Carmen, R. \& Wyatt, R. J. (1982). Postmortem neurochemical studies in chronic schizophrenia. In Biological Markers in Psychiatry and Neurology (ed. I. Hanin and E. Usdin), pp. 67-76. Pergamon Press: Oxford. Lee, T., Seeman, P., Tourtelotte, W. W., Farley, I. J. \& Hornykiewicz, O. (1978). Binding of ${ }^{3} \mathrm{H}$ neuroleptics and ${ }^{3} \mathrm{H}$ apomorphine in schizophrenic brains. Nature 274, 897-900.

Lentz, T. L., Burrage, T. G., Smith, A. L., Crick, J. \& Tignor, G. H. (1982). Is the acetylcholine receptor a rabies virus receptor? Science 215, 182-184.

Liederman, R. R. \& Prilipko, L. L. (1976). The behavior of $T$ lymphocytes in schizophrenia. In Neurochemical and Immunologic 
Components in Schizophrenia (ed. D. Bergsma and A. Goldstein), pp. 365-377. Alan R. Liss: New York.

Maclean, P. D. (1952). Some psychiatric implications of physiological studies on fronto-temporal portion of the limbic system (visceral brain). Electroencephalography and Clinical Neurophysiology 4. $407-418$.

Meyer, A. (1952). Critical evaluation of histopathological findings in schizophrenia. In Proceedings of the First International Congress of Neuropathology, Vol. I, pp. 649-666. Rosenberg \& Sellier: Torino, Italy.

Morgan, L. O. \& Gregory, H. S. (1935). Pathological changes in the tuber cinereum in a group of psychoses. Journal of Nervous and Mental Disease 82, 286-298.

Munzel, P. \& Koschel, K. (1981). Rabies virus decreases agonist binding to opiate receptors of mouse neuroblastoma-rat glioma hybrid cells 108-CC-15. Biochemical and Biophysical Research Communications 101, 1241-1250.

Nieto, D. (1957). Cerebral lesions in schizophrenia. Their neuroanatomical and neurophysiological significance. In Proceedings of the Second International Congress for Psychiatry, Vol. 2, pp. 131-134.

Nieto, D. \& Escobar, A. (1972). Major psychoses. In Pathologv of the Nervous System (ed. J. Minckler), pp. 2654-2665. McGraw-Hill: New York.

Owen, F.. Crow, T. J., Poulter, M., Cross, A. J., Longden, A. \& Riley, G. J. (1978). Increased dopamine receptor sensitivity in schizophrenia. Lancet ii, 223-225.

Pandey, S., Gupta, A. K. \& Shaturvedi, U. C. (1981). Autoimmune model of schizophrenia with special reference to antibrain antibodies. Biological Psychiatry 16, 1123-1136.

Plum, F. (1972). Prospects for research on schizophrenia. 3. Neurophysiology. Neuropathological findings. Neurosciences Re search Program Bulletin 10, 384-388.

Rowland, L. P. \& Mettler, F. A. (1949). Cell concentration and laminar thickness in the frontal cortex of psychotic patients. Journal of Comparative Neurology 90, 255-265.

Scharenberg, K. (1952). Discussion. In Proceedings of the First International Congress of Neuropathology, Vol. 3, pp. 610-623. Rosenberg \& Sellier: Torino, Italy.

Semenov, S. F., Morozov, G. V. \& Kuznetzova, N. I. (1961) Evaluation of the clinical significance of antibrain antibodies in the serum of patients with schizophrenic and other neuropsychiatric disorders. Zhurnal Nevropalologiii Psikhiatrii imeni S. S. Korsakova (Moskva) 61, 1210-1214.

Spielmeyer, W. (1931). The problem of the anatomy of schizophrenia. In Schizophrenia (Dementia Praecox). An Investigation of the Most Recent Advances. Research Publications, Vol. 10. Williams \& Wilkins: Baltimore.
Stevens, J. R. (1976). Computer analysis of the telemetered EEG in the study of epilepsy and schizophrenia. Acta neurochirurgica (Suppl.) 23, 71-84.

Stevens, J. R. (1982a). Neuropathologic changes in schizophrenia: search for a virus. In Proceedings of the Psychobiology of Schizophrenia (ed. M. Namba \& H. Kaiya). Japan (in the press).

Stevens, J. R. (1982b). Neuropathologic changes in schizophrenia. Archives of General Psychiatry (in the press).

Sievens, J. R., Bigelow, L.. Denney. D., Lipkin. J., Livermore, A. Jr, Rauscher, F. \& Wyatt, R. J. (1979). Telemetered EEG-EOG during psychotic behaviors of schizophrenia. Archives of General Psychiatry 36, 251-262.

Tanaka, T., Hazama. H., Kawakara, R. \& Kobayuslu, K. (1981). Computerized tomography of the brain in schizophrenic patients. Acta psychiatrica scandinavica 63, 191197.

Torrey, E. F. (1980). Schizophrenia and Civilization. Jason Aronson: New York.

Torrey, E. F. \& Torrey. B. B. (1979). A shifting seasonality of schizophrenic births. British Journal of Psychiatry 134, $183-186$.

Torrey, E. F., Yolken, R. H.\& Winfrey, C. J.(1982). Cytomegalovirus antibody in cerebrospinal fluid of schizophrenic patients. Science 216, 892-893.

Tyrell, D. A. J.. Crow, T. J.. Parry. R. P.. Johnstone, E. \& Ferrier, I. N. (1979). Possible virus in schizophrenia and some neurological disorders. Lancet ii, 839-841.

Vanderhorst, L. (1952). Histopathology of clinically diagnosed schizophrenic psychosis or schizophrenia-like psychoses of unknown origin. In Proceedings of the First International Congress of Neuropathology, Vol. 3.pp. 648 659. Rosenberg \& Sellier: Torino, Italy.

Vogt, C. \& Vogt. O. (1952). Alterations anatomiques de la schizophrénie et dautres psychoses dites fonctionelles. In Procedings of the First International Congress of Neuropathology, Vol. 1, pp. 516-532. Rosenberg \& Sellier: Torino, Italy.

Weinberger, D. R., Torrey, E. F., Neophytides, A. N. \& Wyatt, R. J. (1979). Lateral cerebral ventricular enlargement in chronic schizophrenia. Archives of General Psychiatry 36. 735739.

Weinberger, D. R., Kleinman, J. E., Luchins, D. J., Bigelow, L. B. \& Wyatt, R. J. (1980). Cerebellar pathology in schizophrenia: A controlled post-mortem study. American Journal of Psychiatry 137. 359-361.

Winkelman, N. W. \& Book, M. H. (1949). Observations on the histopathology of schizophrenia. I. The cortex. American Journal of Psychiary. 105, 889-896. 